\title{
Marine or freshwater? Accessing the paleoenvironmental parameters of the Caldas Bed, a key marker bed in the Crato Formation (Araripe Basin, NE Brazil)
}

\author{
Filipe Giovanini Varejão ${ }^{*}$ (D), Victor Ribeiro Silva ${ }^{2,3}$ (D), Mario Luis Assine² (D, \\ Lucas Veríssimo Warren² (D), Suzana Aparecida Matos ${ }^{3}$ (D), Mariza Gomes Rodrigues ${ }^{2,3}$ (D), \\ Franz Theodor Fürsich ${ }^{4}$ (D) Marcello Guimarães Simões ${ }^{3}$ (D)
}

\begin{abstract}
The Aptian Crato Formation is world renowned for its well-preserved fossils in microbially-induced laminated limestones, which are regarded as one of the main Cretaceous Konservat-Lagerstätte of the geological record. Detailed stratigraphic investigation and mapping of the up to 90-m-thick Crato Formation at the eastern border of the Araripe Plateau allowed recognition of a regionally persistent fossil-bearing muddy interval, herein defined as the Caldas Bed. At its type locality, it is defined as an up to 2-m-thick coarsening-upward succession of grey/green mudstone and interbedded sandy siltstone and claystone. The 0.85 - to 2 -m-thick interval was recognized in several localities along the outcrop belt, and it is bounded by sharp, lower (Konservat-Lagerstätte limestone) and upper (sandstone and heterolithic facies) contacts. Despite previous literature data suggesting the presence of marine mollusks, the bed contains freshwater bivalves, small gastropods, spinicaudatans, plant remains, trace fossils, and rare ostracods. The Caldas Bed records benthic paleocommunities representing a short-term isochronous regional freshening event, marked by abrupt changes in sedimentation pattern, bathymetry, salinity, oxygenation and water chemistry.
\end{abstract}

KEYWORDS: freshwater mussels; gastropods; trace fossils; lacustrine deposits; marker bed; Aptian.

\section{INTRODUCTION}

The Aptian Crato Formation of the Santana Group (sense Assine et al. 2014, Neumann and Assine 2015), Araripe Basin, northeastern Brazil, is worldwide renowned for its exceptionally well-preserved fossils, which are found in lacustrine laminated limestones (Heimhofer et al. 2010, Varejão et al. 2019a). These encompass one of the main Cretaceous Konservat-Lagerstätten of the Gondwana supercontinent (Maisey 1991, Martill et al. 2007a, Varejão et al. 2019a).

Based on the absence of true marine fossils (Neumann et al. 2003, Heimhofer et al. 2010) and the occurrence of

${ }^{1}$ Instituto LAMIR, Departamento de Geologia, Universidade Federal do Paraná - Curitiba (PR), Brazil. E-mail: filipe.varejao@hotmail.com

${ }^{2}$ Departamento de Geologia, Instituto de Geociências e Ciências Exatas, Universidade Estadual Paulista "Júlio de Mesquita Filho", Rio Claro (SP), Brazil. E-mails: victor.r.silva994@gmail.com, mario.assine@unesp.br, lucas.warren@unesp.br, marizagomesrodrigues@gmail.com

${ }^{3}$ Instituto de Biociências, Universidade Estadual Paulista "Júlio de Mesquita Filho”, Botucatu (SP), Brazil. E-mails: sumatos.s@gmail.com, profmgsimoes@gmail.com

${ }^{4}$ GeoZentrum Nordbayern, FG Paläoumwelt, Friedrich-AlexanderUniversität Erlangen-Nürnberg - Erlangen, Germany. E-mail: franz. fuersich@fau.de

${ }^{*}$ Corresponding author. spinicaudatan crustaceans (former conchostracans), ostracods and other non-marine fossils in some particular strata (e.g., Coimbra et al. 2002, Neumann et al. 2003), the Crato Formation is interpreted as a mixed carbonate-siliciclastic succession exclusively deposited in a lacustrine system (Martill et al. 2007a). However, this scenario is not entirely corroborated by recent sedimentological and paleontological data (i.e., Goldberg et al. 2019, Varejão 2019). The sedimentary facies, microfossil and trace fossil content, and stratigraphic architecture of the Crato Formation attest to local influences of marginal marine sedimentation (Varejão 2019), suggesting that the depositional history of this unit is much more complex than previously thought. Also, marine bivalves have been pointed to exist in a muddy interval immediately above the Konservat-Lagerstätte (Barbosa et al. 2004, Bruno and Hessel 2006), although there is no formal description of them (see discussion in Silva et al. 2020a, 2020b).

Indeed, the distinction between marine and non-marine settings under the influence of epicontinental seas - as is the case of the Araripe Basin (Arai 2014, Assine et al. 2016, Custódio et al.2017, Fürsich et al. 2019, Goldberg et al.2019, Varejão et al. 2019b, Rodrigues et al.2020) — is a complicate issue in basin analysis especially when ambiguous body and trace fossils are recorded in the preserved assemblages (e.g., Barnes 1989, Buatois et al. 1997, Gomez et al. 2009, Keller et al. 2009, Gross et al. 2016, Quijada et al. 2016, Mas et al. 2018, 
Bright et al. 2018). In this way, the use of multiple geological tools (e.g., sedimentological, stratigraphic, paleontological, geochemical approaches) is advisable in order to confidently identify the depositional environments and their vertical and lateral variations (e.g., Wesselingh et al. 2002).

The recognition of intervals with paleoenvironmental and paleogeographic significance is of ultimate importance for better characterizing the depositional record of the Crato Formation. Within the last years, during detailed mapping and stratigraphic investigation of the formation within the scope of a broad investigation of the Santana Group (i.e., Assine et al. 2014, Catto et al. 2016, Assine et al. 2016, Warren et al. 2017, Custódio et al. 2017, Fürsich et al. 2019, Varejão et al. 2019b, Silva et al. 2020a, Silva et al. 2020b, Rodrigues et al. 2020), we were able to:

- establish a stratigraphic-sedimentologic framework of the fossil occurrences other than those tied to the fossil-rich laminated limestones;

- identify intervals that are regionally relevant for paleoenvironmental interpretations and basin-wide correlation.

Among such intervals, the Caldas Bed is here formally described as a datum for intrabasinal stratigraphic correlation, and a key bed in order to discuss the existence of short-lived marine incursions in the Aptian Crato Formation.

\section{GEOLOGICAL SETTING}

The Mesozoic Araripe Basin developed within the Borborema Province, interior of northeastern Brazil, by reactivation of faults associated with the Neoproterozoic Patos shear zone, in response to stresses transmitted to the plate interior during the opening of the southern and equatorial branches of the Atlantic Rift System (Matos 1992). The Aptian transitional phase of the Araripe Basin is represented by the Barbalha, Crato, Ipubi and Romualdo formations that constitute the Santana Group (Assine et al. 2014, Neumann and Assine 2015). These units comprehend mixed carbonate-evaporite-siliciclastic depositional system tracts (Assine et al. 2014, Fig. 1) related to short-lived marine ingressions (Arai 2014, Assine et al. 2016, Custódio et al. 2017, Fürsich et al. 2019, Varejão et al. 2019b, Rodrigues et al. 2020).

The Crato Formation, an up to 90 -m-thick succession of interbedded limestone, shale, mudstone and sandstone, is one of the most-studied Aptian units of the Araripe Basin due to its fossil content (Figs. 1 and 2). It is usually interpreted as deposited in a lacustrine system due to the presence of continental fauna and flora, kerogen type, and particular carbon and oxygen isotopic values (Neumann et al. 2003, Heimhofer et al. 2010). The Crato Formation contains abundant and exceptionally preserved continental fossils that underwent microbial entombment (Varejão et al. 2019a), making it one the most important

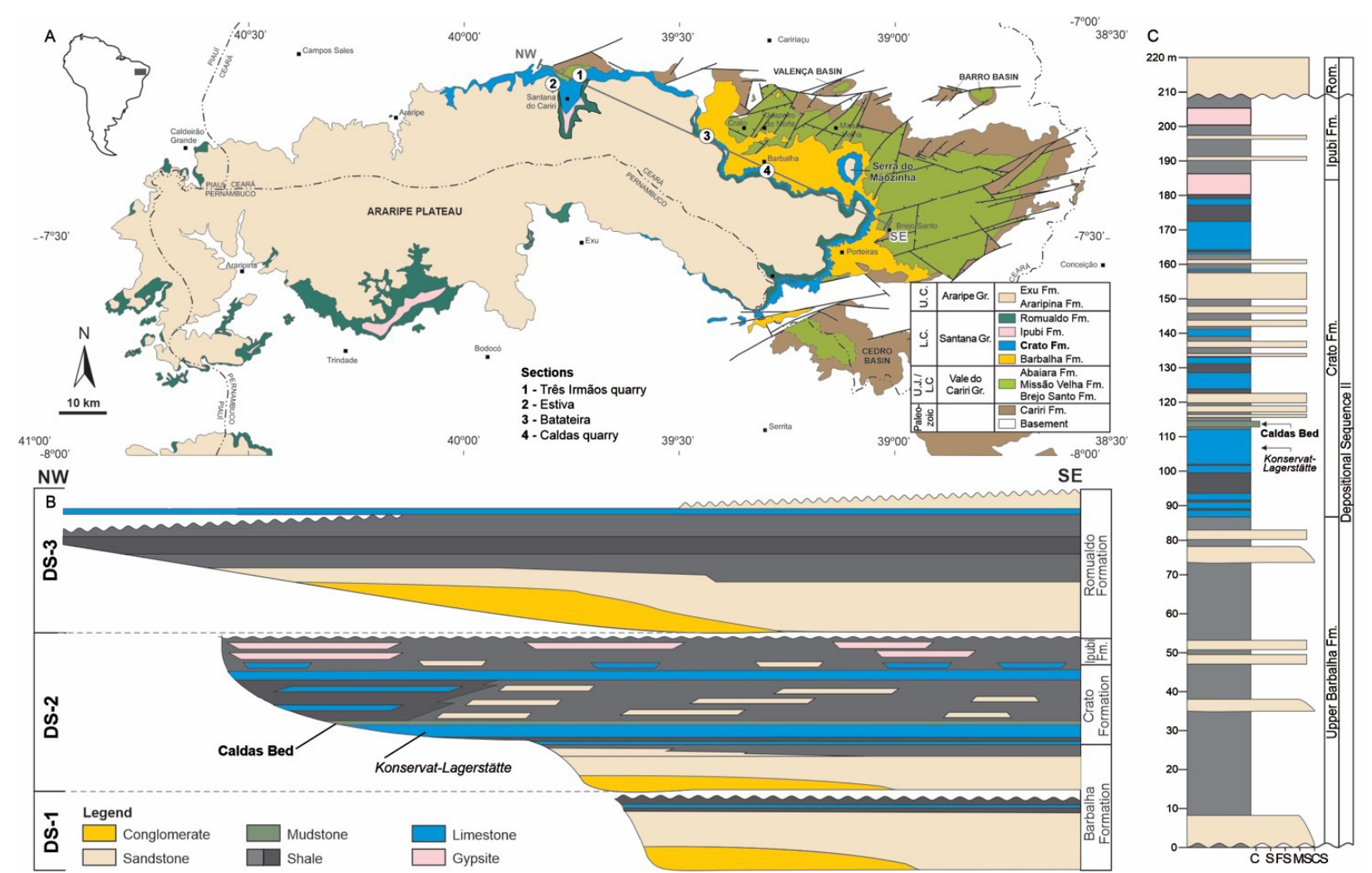

Gr.: group; Fm.: formation; DS: depositional sequence; C: clay; S: silt; FS: fine sand; MS: medium sand; CS: coarse sand; U.C.: Upper Cretaceous; L.C.: Lower Cretaceous; U.J.: Upper Jurassic.

Figure 1. Stratigraphic framework of the Caldas Bed. (A) Geologic map of the Araripe Basin with the location of the columnar sections where the Caldas Bed was described (modified from Assine et al. 2014). (B) Depositional sequences of the Aptian Santana Group and the stratigraphic position of the Caldas Bed within the Crato Formation (modified from Assine et al. 2014). (C) Stratigraphic architecture of the Depositional Sequence II (Assine et al. 2014), with the position of the Caldas Bed above lacustrine limestones with exceptional fossil preservation. 
Braz. J. Geol. (2021), 51(1): e2020009

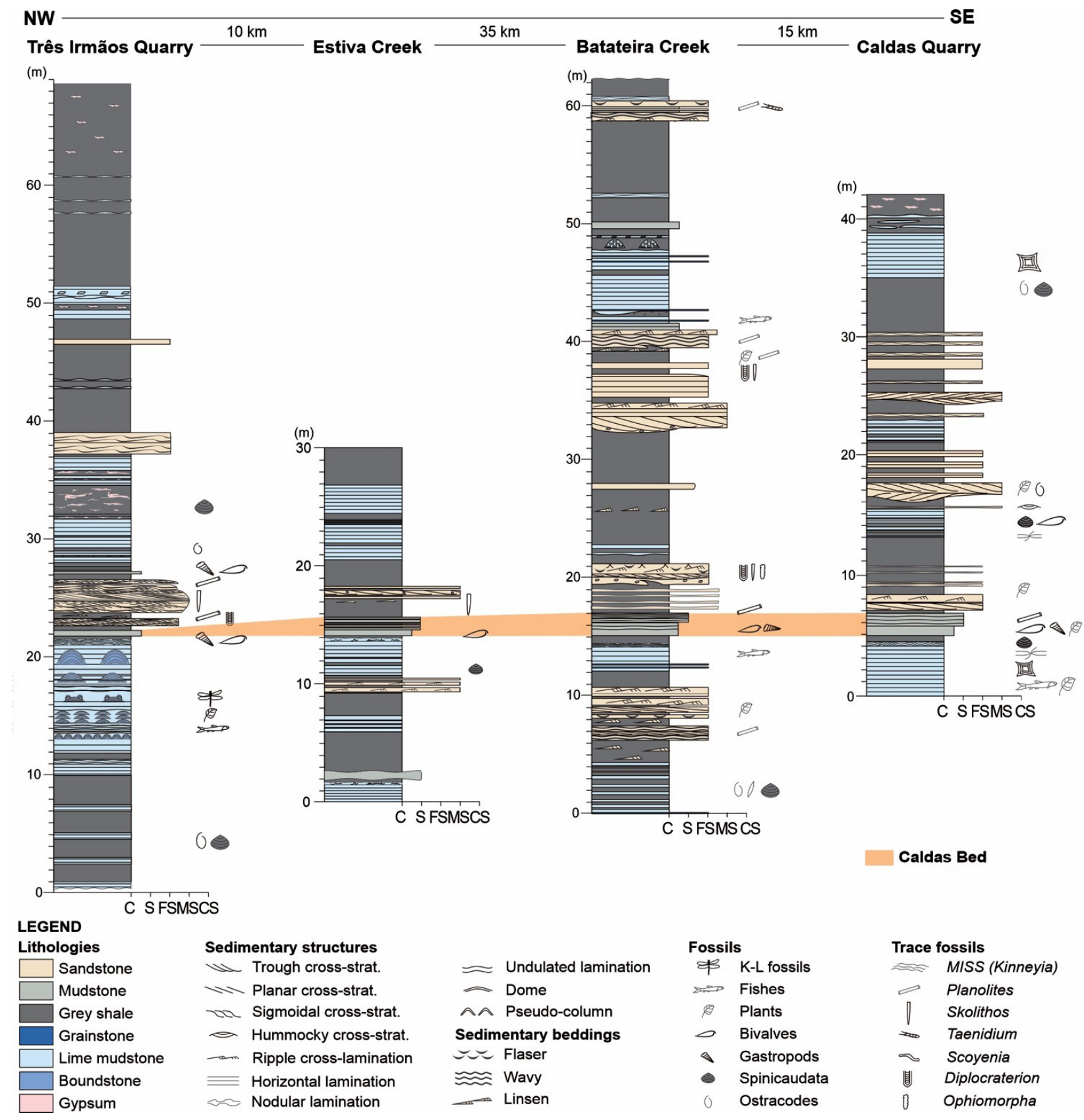

C: clay; S: silt; FS: fine sand; MS: medium sand; CS: coarse sand.

Figure 2. Columnar sections of the Crato Formation highlighting the occurrence of the Caldas Bed.

Cretaceous Konservat-Lagerstätten worldwide (Maisey 1991, Heads et al. 2008, Martill et al. 2007a). Arthropods, fishes, turtles, pterosaurs, gymnosperms, and early flowering plants are recognized as the best-preserved fossils (Martill et al. 2007a), and thrived in the margins of a lacustrine system under frequent hypersaline and alkaline conditions (Martill et al. 2007b, Heimhofer et al. 2010, Warren et al. 2017).

Fossils are otherwise rare in other strata of the Crato Formation and only continental spinicaudatans and palynomorphs are abundant along the unit (Coimbra et al. 2002, Neumann et al. 2003, Heimhofer and Hochuli 2010). Until recently, the apparent absence of typical marine fossils led to the interpretation of the whole unit as a mixed lacustrine system, with carbonate deposition in distal settings and siliciclastic sedimentation in the marginal areas (Neumann et al.2003). However, the recent record of microforaminifers at the top of the Crato Formation, right below the evaporite beds (Goldberg et al. 2019), and of dinocysts and typical marine ichnotaxa at the base of the unit (Varejão 2019), indicate that intervals punctuated by short-lived marine incursions occurred during its depositional history. Also, tidal rhythmites, tidal bundles, and marine ichnotaxa (Arenicolites isp., Diplocraterion isp., and Skolithos isp., of the Skolithos Ichnofacies) have been recognised, reinforcing the punctual marine influence in the deposition of the unit (Varejão 2019).

\section{THE MOLLUSKS OF THE CRATO FORMATION}

Beurlen (1963, p. 15) was one of the first authors to note the presence of mollusk fossils in the Crato Formation. This assemblage was originally described as mainly dominated by small 
unionid bivalves, commonly in association with plant remains. Beurlen (1963) collected some specimens from a dark mudstone at the so-called Romualdo Ranch in the vicinity of the town of Crato, but neither the shells nor the mudstones were originally illustrated or described by this author. Bivalves in the Crato Formation were also mentioned by Mabesoone and Tinoco (1973), mainly based on the imprecise data of Beurlen (1963).

Martill and Wilby (1993), and Martill et al. (2005, 2007a, $2007 b$ ) were the first authors to clearly state that the bivalves of the Crato Formation occur in mudstones stratigraphically above the top of the fossil-bearing laminated limestones from the base of the unit. Martill et al. (2005, p. 1402) also preliminary observed that the bivalves were probably unionids. In a note published at a regional meeting, Barbosa et al. (2004) recorded the bivalve-bearing mudstones of the Crato Formation in localities at the eastern part of the Araripe Basin, in the sedimentary succession cropping out at the Batateira creek, or in mining outcrops, such as the Caldas, André (= Três Irmãos) and Pedra Branca quarries, in the State of Ceará. In all these localities, the bivalve-bearing mudstones overlie the topmost laminated limestone unit (Barbosa et al. 2004).

Barbosa et al. (2004) cited the presence of marine bivalves, such as Yoldia (Yoldia) sp., Barbatia (Cucullaearca) sp., and Malletia (Malletia) sp., plus the freshwater genus Pseudohyria. Again, the bivalves were not illustrated or described. Based on data in Barbosa et al. (2004), Bruno and Hessel (2006) noticed on the presence of these marine and freshwater genera in the Crato Formation, suggesting that they may have lived under euryhaline conditions.

Based on the few data available, Van Damme et al. (2015, p. 189) stated that the record of "unionid bivalves" in the upper part of the Early Cretaceous Crato Formation could not be considered a valid occurrence due to lack of formal taxonomic description. However, very recent taxonomic studies of the bivalve mollusks of the Crato Formation have confirmed the presence of a striking freshwater mussel fauna (Unionida) in this unit (Silva et al. 2020a, Silva et al. 2020b). According to these new available data, it was possible to establish that the bivalve assemblage is mainly represented by three distinct families, Silesunionoidea, Trigonioidoidea, and possibly Hyriidae (Silva et al.2020a, Silva et al.2020b). The fauna is dominated by specimens of Araripenaia elliptica (Hyriidae or Trigonioidoidea), followed by Monginellopsis bellaradiata (Trigonioidoidea), and Cratonaia novaolindensis (Silesunionoidea) (Silva et al.2020a, 2020b). However, only Araripenaia elliptica is widely distributed within the mudstone bed above the laminated limestone and can be regarded as the most representative fossil of this interval. The bivalves were probably semi-infaunal to infaunal, suspension feeding forms adapted to live in the muddy substrates with very slow-flowing waters.

The presence of gastropods in the Crato Formation was recognized in the literature only by Santos et al. (2017). The gastropods were described in the mudstone bed above the fossiliferous laminated limestone, and also in siltstone with ripple cross-lamination, approximately $17 \mathrm{~m}$ above the mollusk-bearing mudstone (Santos et al. 2017). According to these authors, hydrobiids typically colonized the muddy substrates in freshwater and brackish water environments (Kabat and Hershler 1993). Other conispiral morphotypes exhibit axial ornamentation, typical of some marine and brackish water rissoid gastropods (Ponder 1984).

\section{METHODS AND DATASETS}

The recognition of the Caldas Bed as a key marker bed within the Crato Formation was based on the Article B-7 of the Brazilian Stratigraphic Code of Nomenclature (see Petri et al. 1986, p. 373-374). Data is derived from a broad, detailed regional stratigraphic mapping (1:25.000) of this unit combined with a high-resolution outcrop logging. The main localities of the bed are:

- the Caldas quarry (24 M 459,410/9,186,889);

- Estiva creek (24M 413,948/9,210,049);

- Três Irmãos quarry (24M 422,971/9,213,396);

- the Batateira creek $(24 \mathrm{M} 449,866 / 9,198,487)$, all in the southeastern part of the State of Ceará.

The bed name is derived from its most representative outcrop in the Caldas quarry, municipality of Barbalha.

High resolution (1:20) columnar sections of the Crato Formation were measured along the eastern border of the Araripe Plateau. The detailed logs allowed the recognition of an interval of grey mudstones above the fossiliferous laminated limestones at base of the unit with regional distribution, containing a unique mollusk assemblage (Silva et al. 2020a, Silva et al.2020b). Description of the sedimentary facies was based on geometry, texture, sedimentary structures, paleocurrents, taphonomic signatures, body fossil content, trace fossil associations, and carbon and oxygen isotopic composition (following conceptual framework summarized in Hoefs 2004, Buatois and Mángano 2011, Miall 2016). The distinct characteristics of this specific interval and stratigraphic position within the Crato Formation succession allowed its definition as a single and laterally traceable bed with basin-wide extension.

Mudstone samples were collected in different measured sections of the studied interval for carbon and oxygen isotopes. The carbonate powders (10 samples) were drilled avoiding fractured, weathered and mineral-filled zones. These were reacted with $100 \% \mathrm{H}_{3} \mathrm{PO}_{4}$ under $\mathrm{He}$ atmospheric conditions. The extracted $\mathrm{CO}_{2}$ was measured for carbon and oxygen isotopic compositions in a Delta Advantage mass spectrometer in the LAMIR Institute from the Universidade Federal do Paraná (UFPR). Isotopic results are reported in the conventional per-mil delta notation $\left(\delta^{13} \mathrm{C}\right.$ and $\left.\delta^{18} \mathrm{O}\right)$ with respect to Vienna Pee Dee Belemnite (VPDB) and have analytical reproducibility better than \pm 0.1 per mil.

During the field sampling of the Caldas Bed, 433 individuals of mollusks ( 230 freshwater bivalves and 203 gastropods) were collected. They are deposited in the scientific collections of the Universidade Estadual Paulista "Júlio de Mesquita Filho", Botucatu campus, São Paulo, Brazil. The taphonomic signatures of the shells are briefly mentioned, and the main biostratinomic attributes and nomenclature used follows those of 
Kidwell et al. (1986), Brett and Baird (1986), and Fürsich and Oschmann (1993).

The description of the trace fossils followed the conceptual framework summarized in Buatois and Mángano (2011). When possible, the trace fossils were classified taxonomically. The degree of bioturbation was also estimated based on the Taylor and Goldring (1993) scheme, who defined a bioturbation index (BI), ranging from zero (no bioturbation) to six (complete bioturbated).

\section{CALDAS BED: FORMAL PROPOSITION}

Within the sedimentary succession of the Crato Formation, a relatively thin ( $\sim 0.3$ to $2 \mathrm{~m})$ mollusk-bearing mudstone, and interbedded sandy siltstone and claystone with abundant horizontal trace fossils, is readily recognizable immediately above the topmost laminated limestone bed of the Lagerstätte interval at the basal interval of the unit (Figs. 1, 2, and 3). This interval is clearly distinct from the successions above and below given its distinct physical sedimentary properties and/or fossil content. The mud-dominated succession was recognized along the outcrop belt of the Crato Formation in the Nova Olinda, Crato and Barbalha municipalities, State of Ceará (Fig. 1), and is here formally recognized as the Caldas Bed, as follows.

\section{Formal proposition}

Category: Lithostratigraphic unit.

Hierarchy: Bed.

Derivation of name: Caldas Bed, given that the best exposures of this bed are located at excavation sites of the IBACIP (Barbalhense Industry of Portland Cement), Barbalha County, Ceará State, NE Brazil (Fig. 3).

Type locality: The Caldas quarry (24M459,410/9,186,889), Barbalha County (Fig. 3).

Description: At its type locality, the Caldas Bed is a 2-m-thick coarsening-upward succession characterized at the base by a 0.9-m-thick mudstone bed and at top by a 1.1-m-thick interbedded succession of sandy siltstone and claystone containing abundant horizontal trace fossils. The succession occurs right above the limestones of the Konservat-Lagerstätte that are also traceable at basin scale (Fig. 4A). Laterally, the succession may lay on up to 0.2 -m-thick grey shales with interbedded tabular beds of mudstone.

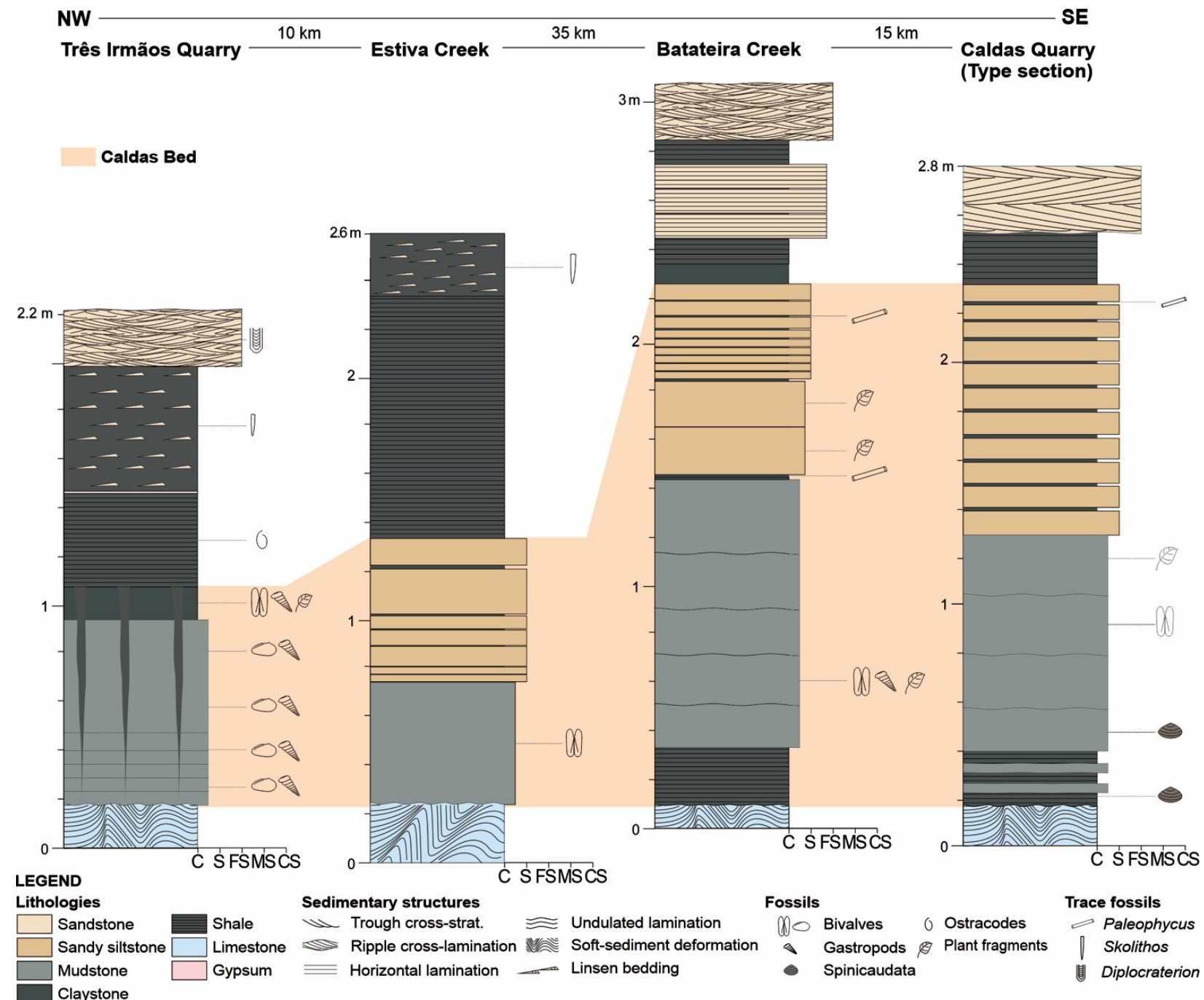

C: clay; S: silt; FS: fine sand; MS: medium sand; CS: coarse sand.

Figure 3. Correlation of columnar sections highlighting the Caldas Bed. 

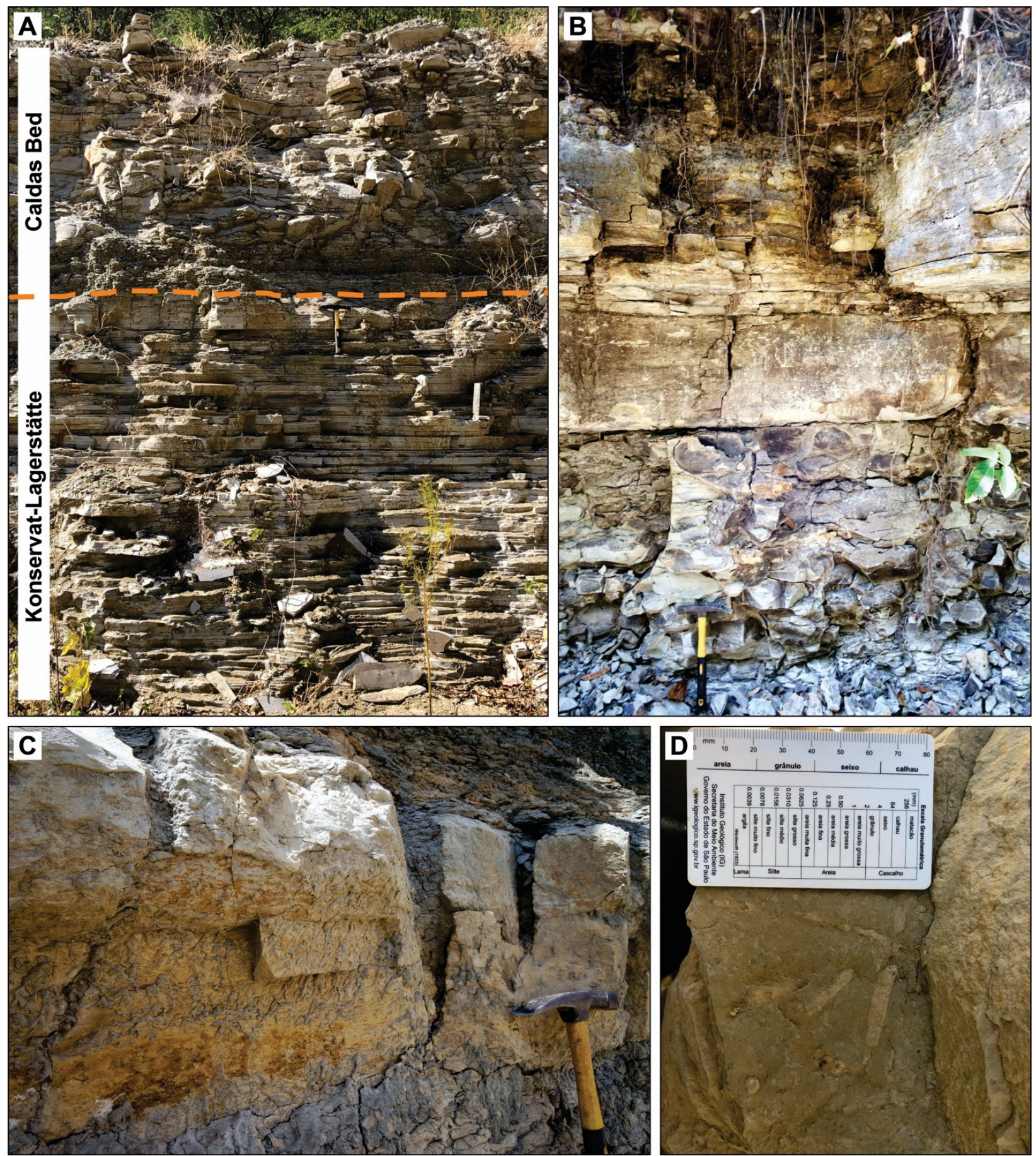

Figure 4. Main sedimentological features of the Caldas Bed at different areas. (A) Caldas Bed in its type section right above the Konservat-Lagerstätte. (B) Thickening-upward pattern observed in the predominantly muddy succession. (C) V-shaped cracks filled by claystone at Nova Olinda section. (D) Trace fossils preserved in hyporelief. Hammer in A-C is 30-cm long, and scale bar in D is $8 \mathrm{~cm}$ in length.

The grey- to green-colored mudstones occur in sharp and abrupt contact with limestone at base of the succession. They are organized in $\mathrm{cm}$-scale structureless tabular beds with undulated base and flat top, without evidence of bioturbation. Where shales are intercalated between limestone and mudstone, a transitional contact is observed between these facies. Spinicaudatan remains are recorded at the base of the mudstone, while typical freshwater bivalves (Unionida) occur in the middle, and carbonized plant fragments are common in the upper part of the mudstone bed. The bivalves (resembling modern and fossil Hyriidae from the Americas, Trigonioidoidea from Eurasia and north Africa, and Silesunionoidea from
Europe; see Silva et al.2020a, Silva et al.2020b) are dispersed in the mudstone and are mainly represented by articulated valves, especially splayed-out ones. The shells are commonly articulated, mainly in butterfly posture. When closed articulated, most of the shells are with the umbones downwardly oriented, with the antero-posterior axis of the shells arranged at low angles with the bedding plane. Disarticulated shells are typically arranged concordant to bedding, either convex-up or down. Among the disarticulated specimens the number of right and left valves is similar (i.e., no 50:50 left/right valve deviation is noted). Hence, the bivalves are probably autochthonous to parautochthonous elements (sensu Kidwell et al. 
1986) in the Caldas Bed and a prime indicator of freshwater conditions.

Above the fossil-rich mudstones, the succession is dominated by interbedded $\mathrm{cm}$-thick tabular beds of sandy siltstones ( 2 to $10 \mathrm{~cm}$ ) and claystone $(0.5$ to $2 \mathrm{~cm}$ ), confirming the coarsening-upward pattern of the association. The siltstone beds form a thickening- and coarsening-upward succession, and the base of each bed commonly display moderate to abundant (BI-3) positive hyporeliefs of horizontal simple trace fossils (i.e., Planolites montanus). The top of the succession is flat and the contact with the overlying shales abrupt.

\section{Regional attributes}

As mentioned above, the bivalve-bearing muddy interval of the Caldas Bed can be recognized at different localities of the Araripe Basin (Figs. 1 and 2). All other three sites (i.e.,
Estiva and Batateira creeks and Três Irmãos quarry; Figs. 3, 4, 5 , and 6) exhibit the same stratigraphic, sedimentologic and paleontological attributes.

\section{Três Irmãos section}

In this section, the Caldas Bed is confined to a mudstone bed laterally varying in thickness between 0.3 and $0.85 \mathrm{~m}$. It is intercalated between fossil-rich laminated limestones and a heterolithic succession. The latter consists of a mud-dominated interval characterized by up to 0.3 -m-thick layers of massive mudstones with interbedded claystone and gypsum up to $2 \mathrm{~cm}$ in thickness. The Caldas Bed occurs just above the laminated limestones that constitute the Konservat-Lagerstätte of the Crato Formation (Fig. 6A). Small gastropods are common in the lower part, while bivalves dominate the upper part of the mudstone bed. The bivalves (Cratonaina novaolindensis, Monginellopsis
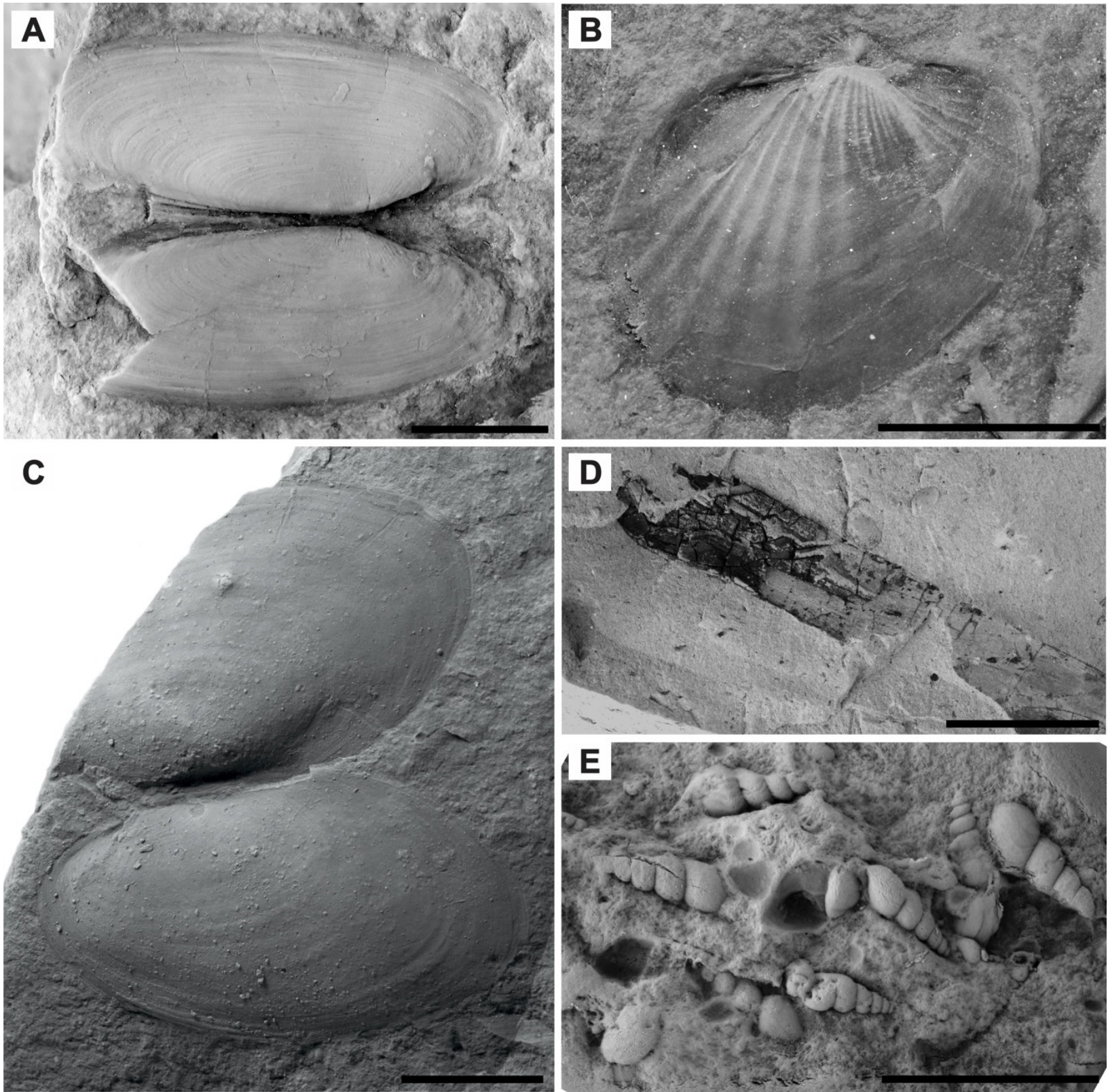

Figure 5. Characteristic fossils from the Caldas Bed, including Unionida bivalves (A-C), carbonized plant remains (D), and possibly hydrobiid gastropods (E). Explanation: (A) Araripenaia elliptica (Hyriidae or Trigonioidoidea), (B) Monginellopsis bellaradiata (Trigonioidoidea), (C) Cratonaia novaolindensis (Silesunionoidea). Scale bars are $2 \mathrm{~cm}$. 

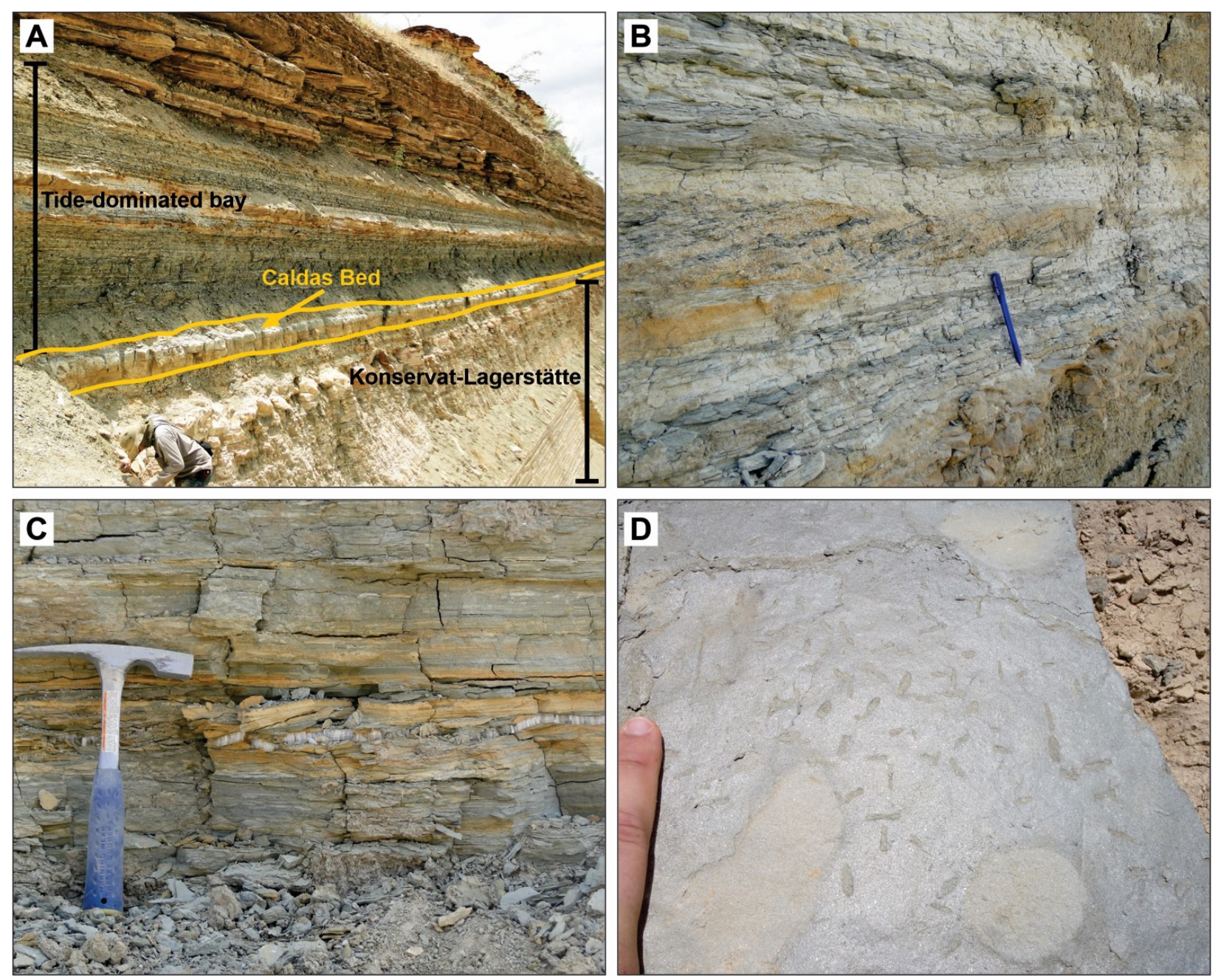

Figure 6. Stratigraphic relationship of the Caldas Bed with strata below and above. (A) Três Irmãos quarry showing the vertical position of the Caldas Bed. (B) Heterolithic succession of interbedded sigmoidal cross-stratified sandstone and heterolithic beddings. Pencil is 12 -cm long. (C) Rhythmic interbedding of sandstone and mudstone layers. Note the presence of gypsum. Hammer is $30-\mathrm{cm}$ long. (D) Dumbbell-shaped trace fossils (i.e., Diplocraterion isp.).

bellaradiata, and Araripenaia elliptica) occur as dispersed articulated or disarticulated valves preserved as internal, external or composite molds. Some specimens with closed articulated shells are probably in situ (i.e., in life position). The mudstone is intensely bioturbated, so that any original fabric has been obliterated, presenting a mottled aspect. It is overlain by claystone with incipient lamination. These are characterized by dispersed bivalve shells (mostly Araripenaia elliptica) that are commonly articulated and predominantly preserved as splayed open valves. The entire interval has a flat base and an erosional irregular top, which is dissected by several irregular V-shaped cracks (up to 30 $\mathrm{cm}$ deep and with a top width varying between 3 and $10 \mathrm{~cm}$ ), parallel to each other and filled with mud. Above the Caldas Bed, there is a meter-scale succession including channelized sandstone and heterolithic facies (Fig. 6A). Sandstone with trough and sigmoidal cross-stratification commonly contain mudstone-drapes bounding sets and foresets, while rip-up mudstone intraclasts are common in the foresets (Fig. 6B). Finer-grained sandstone displaying horizontal stratification and asymmetric ripple cross-lamination occur interlaminated with mudstone (flaser/ wavy bedding) (Fig. 6C). The succession is also characterized by sparsely to moderately bioturbated $(\mathrm{BI}=2-3)$ intervals with
Arenicolites isp., Diplocraterion isp., and Skolithos isp. (Figs. 6C, and 6D). The heterolithic succession is interpreted as deposited in tidal flats due to the occurrence of tidal bundles and tidal rhythmites associated to the Skolithos Ichnofacies.

\section{Estiva section}

The Caldas Bed is a 1.1-m-thick coarsening-upward succession of mudstone and interbedded sandy siltstone and claystone. Gray to green mudstones contain shells of freshwater bivalves (Araripenaia elliptica) right above shales or limestones of the Konservat-Lagerstätte interval. As usual, the bivalves are dispersed to loosely packed in the sedimentary matrix, mainly concordant (convex-up) to bedding. Both articulated and disarticulated shells occur, but most of them are specimens with splayed valves. Thickening-upward tabular layers of sandy siltstones are interbedded with claystones and occur towards the top. Incipient lamination disrupted by horizontal trace fossils (Planolites isp.) occur in the sandy siltstones.

\section{Batateira creek section}

At this outcrop, the Caldas Bed consists of 0.25 -m-thickblack shale that is followed by $1.1-\mathrm{m}$-thick tabular gray mudstones. 
The latter are mainly massive, although incipient lamination highlighted by horizontal traces can be observed. In the basal interval, bivalves (Araripenaia elliptica) are the dominant fossils. They are dispersed and typically preserved as splayed open individuals, while gastropods occur as subordinate elements. The number of right and left valves is roughly the same. Isolated valves commonly occur in a convex-up position. The succession thickens towards the top of the bed (Fig. 4B). The Caldas Bed is overlain by a 0.9 -m-thick succession of tabular beds of sandy siltstone with faint lamination that are separated by thin claystone layers with sandy siltstone-filled burrows (Palaeophycus; Fig. 4D).

\section{LITHOSTRATIGRAPHIC, BIOSTRATIGRAPHIC AND CHEMOSTRATIGRAPHIC TRAITS}

The fossiliferous laminated limestones (KonservatLagerstätte) forming the lower part of the Crato Formation are sharply covered by a muddy interval (i.e., Caldas Bed) that can be easily traced for tens of kilometers along the eastern border of the Araripe Basin (Figs. 2 and 3). The thickness of the Caldas Bed decreases towards the northwestern margin, though the mollusk-bearing assemblages are much more abundant and diverse in this part of the basin. In this area (i.e., at the Três Irmãos quarry), claystone-filled, V-shaped cracks are recorded in the mudstone (Fig. 4C) documenting a crucial event that took place after the deposition of the Caldas Bed. These structures are probably associated with subaerial exposure of the substrate or to syn-sedimentary seismicity (i.e., type 3 sedimentary dike, see Törő and Pratt 2016, p. 189 and p. 195). However, the exact origin of the V-shaped features could not be verified and further investigation is needed. Towards southeast, the thickness of this marker bed increases, and the muddy facies is overlain by coarser-grained facies forming a typical coarsening-upward succession (Fig. 3).

The Caldas Bed is characterized by $\delta^{13} \mathrm{C}$ values between $-0.77 \%$ and $+0.5 \%$, while the $\delta^{18} \mathrm{O}$ values range from $-6.9 \%$ o and $-4.48 \%$ (Fig. 7 ), slightly varying along the outcrop area. The mollusk-bearing mudstone has values ranging from $-6.9 \%$ o to $+5.59 \%$ of $\delta^{18} \mathrm{O}$, and from $-0.6 \%$ o to $+0.5 \%$ o for $\delta^{13} \mathrm{C}$. In the upper coarse-grained part (i.e., interbedded sandy siltstone and claystone), the $\delta^{18} \mathrm{O}$ varies from $-5.58 \%$ o to $-4.48 \%$, and between $-0.77 \%$ and $-0.04 \%$ or for $\delta^{13} \mathrm{C}$.

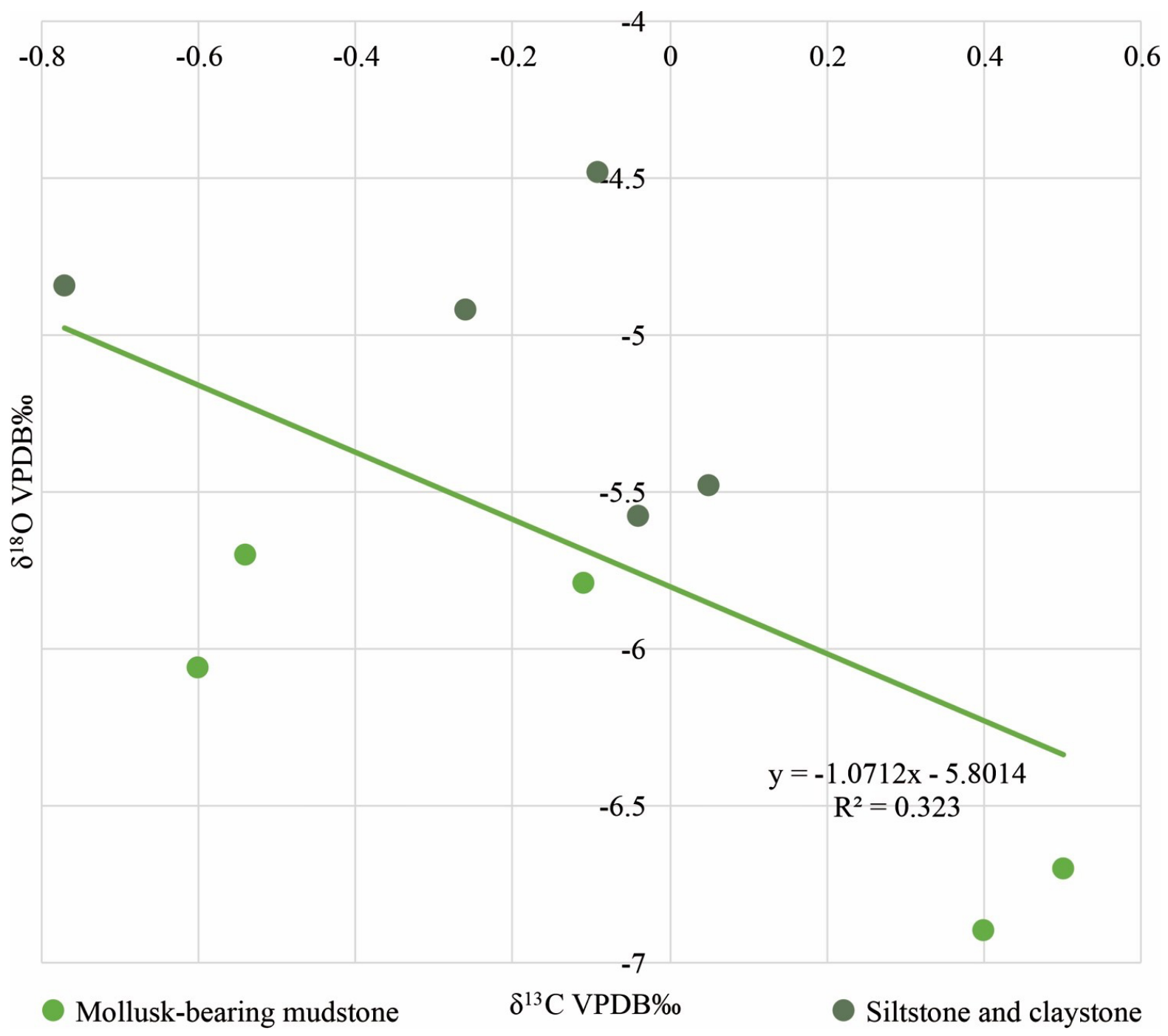

VPDB: Vienna Pee Dee Belemnite.

Figure 7. Carbon and oxygen isotope data of the Caldas Bed. 
The presence of freshwater bivalve shells (Figs. 5A, 5B, and $5 \mathrm{C}$ ) is a key paleontological feature of the Caldas Bed distinguishing the mud-dominated marker bed from the beds immediately below and above. Notably, the occurrence of bivalves in this interval is known since the 1960s, though they have only been formally described recently (see Silva et al. 2020a, Silva et al. 2020b). Carbonized plant fragments (Fig. 5D) are common throughout the Caldas Bed, although they tend to be more abundant in intervals without mollusk remains. Gastropod shells are very common in the Caldas Bed as well, especially in mudstones from the Três Irmãos quarry and the Batateira creek sections (Fig. 5E). The specimens are preserved mainly as tiny $(2.9-12.3 \mathrm{~mm})$ internal and external molds. Fragmentation is uncommon and the specimens are dispersed in the matrix, generally showing compaction-related shell deformations. Conispiral, turriform/fusiform and highspired shells strongly predominate, planispiral shells, in turn, are exceedingly rare. Their poor preservation hampers the precise taxonomic identification; however, the general outline of the commonest morphotypes found in the Caldas Bed resembles the shells of hydrobiids, as previously identified by Santos et al. (2017). These fossils are now under detailed study, and we hope that soon we will be able to provide additional paleoecological data on the depositional history of the Caldas Bed.

\section{PALEOENVIROMENTAL IMPLICATIONS: MARINE VS. NON-MARINE SETTINGS}

Contrary to previous paleontological data (see Barbosa et al. 2004), the Caldas Bed is herein interpreted to have been deposited in a freshwater lacustrine system due to the abundance of non-marine forms (e.g., Unionida, Silva et al. 2020a, Silva et al. $2020 \mathrm{~b}$ ) and its oxygen isotopic composition (between $-6.9 \%$ and $-4.48 \%$ ). Slightly negative carbon isotope values suggest higher primary productivity in surface waters (see Armstrong and Brasier 2005) compared to those observed in carbonates from the Konservat-Lagerstätte. Indeed, Heimhofer et al. (2010) pointed out that the $\delta^{13} \mathrm{C}$ values of the laminated limestone interval range from $-0.1 \%$ o to $+1.9 \%$, reflecting a restricted lacustrine system with stagnant bottom and limited freshwater input (Heimhofer et al. 2010). In this way, the abrupt boundary of the Konservat-Lagerstätte interval and that from the Caldas Bed represents a crucial shift from a closed system to an open one.

As discussed in Silva et al. (2020a) and in Silva et al. (2020b), the commonest bivalves recorded in this marker bed are confidently assigned to true freshwater groups (i.e., naiads) (Silva et al. 2020a, Silva et al. 2020b). The presence of marine or brackish water forms (Yoldia, Barbatia, Malletia; Barbosa et al. 2004) has not yet been confirmed. For example, none of the bivalve specimens in the collections examined by Silva et al. (2020a) and Silva et al. (2020b) has a typical taxodont hinge as in Yoldia or Barbatia.

The freshwater system of the Caldas Bed occupied the entire eastern area of the basin and made possible the proliferation of abundant mollusks, especially bivalves that generated shell-rich beds. Notably, the presence of mollusk-rich horizons is a common feature observed in modern and ancient lacustrine sedimentary successions around the world (Cohen 1989, Gomez et al. 2009). The large amount of articulated shells, the similar left/right valve ratios of disarticulated specimens, and the absence of signs of fragmentation and abrasion are indicative of short residence time in the taphonomically active zone (TAZ, Aller 1982) and low lateral tractive transport. As commented above, the bivalves are clearly autochthonous to parautochthonous, and are more diverse (three coexistent Unionida genera) in the northwestern outcrop area, suggesting the presence of better oxygenated waters in this part of the basin. Indeed, the mottled aspect of the mudstone in the northwestern part suggests that these freshwater mussels lived totally or partially buried within the substrate. Oxygenated waters were probably a product of constant input of freshwaters by drainages in the proximal parts of the lacustrine system (NW area).

In the distal parts of the basin (SE area of the Caldas Bed outcrop belt) and just above the mollusk-rich mudstone, interbedded sandy siltstone and claystone containing Planolites montanus and carbonized plant remains are organized in a thickening- and coarsening-upward pattern. These also suggest an intermittent input of freshwater by adjacent small streams, delivering coarser sediments and plant debris to the basin. Indeed, the oxygen isotopic composition of the lower mudstone layer is more stable than that of the upper coarser-grained layer, implying a marked variation in the salinity of the waters in this last interval.

Above the Caldas Bed, the record of heterolithic facies, tidal bundles and marine ichnotaxa points to yet another change, this time related to a brief marine ingression. This situation is similar to that observed in the Miocene Huesser Horizon, Carbonera Formation, Eastern Cordillera of Columbia (Gomez et al. 2009). There, a well-preserved freshwater mollusk assemblage accumulated in a lake system is capped by a marine incursion, which is related to the increase of subsidence under conditions of sea-level rise (Gomez et al. 2009). As commented before, an alternative hypothesis for the subaerial exposure origin of the V-shaped cracks is a seismic trigger related to earthquakes when the sediments were not yet fully consolidated. This would suggest that the basin was tectonically active at least in part of its sedimentation, as already stated by Miranda et al. (2018). Thus, similarly to the Huesser Horizon, the marine incursion above the Caldas Bed could have been increased by tectonic subsidence rates accompanied by a condition of rising sealevel (see Haq 2014).

In conclusion, the Caldas Bed represents an essential paleoenvironmental change in salinity, pattern of sedimentation, faunal composition, as well as possibly climate, compared to the strata above and below.

\section{FINAL REMARKS}

Detailed stratigraphic study of the Crato Formation of the Araripe Basin allowed us to recognize a set of lithological and paleontological attributes that characterizes the Caldas Bed. This ca. 2-m-thick siliciclastic-dominated interval can be recognized and traced along the outcrop belt of the Crato Formation in the Cariri valley. Geological, paleontological and isotopic informations 
indicate that the bed has been deposited in a freshwater lacustrine system. The Caldas Bed marks an abrupt change in sedimentation, when the hypersaline carbonate-dominated system was replaced by a fine-grained siliciclastic freshwater environment. None of the most common fossils in the bed, the bivalves, can be confidently assigned to marine groups, as the majority belong to freshwater mussels (Unionida). Taphonomic information indicate that these bivalves are autochthonous to parautochthonous elements having thrived in the muddy substrate.

The Caldas Bed is a very useful stratigraphic marker for intrabasinal surficial correlations (Fig. 2), providing a crucial geological tool in regional analyses and geologic mapping. In this context, the Caldas Bed is particularly useful as a stratigraphic datum given its sharp basal contact with the underlying laminated limestones (hypersaline lake) and the overlying heterolithic succession (tide-dominated bay) (Fig. 2). Erosional features and clay-filled fissures at the top of the Caldas Bed at the Três Irmãos section suggest possible syn-sedimentary seismicity or conditions of prolonged subaerial exposure.

\section{ACKNOWLEDGMENTS}

Financial support of this study was provided by the São Paulo State Research Foundation (Fundação de Amparo à Pesquisa do Estado de São Paulo - FAPESP 2016/13214-7; 2017/22036-8; 2017/20803-1; 2018/01750-7). Partial financial support was also offered by $\mathrm{CNPq}(401039 / 2014-5)$, and Petrobras (2014/00519-9). The research was conducted with institutional support of the Universidade Estadual Paulista "Júlio de Mesquita Filho". M.L. Assine, M.G. Simões and L.V. Warren are fellows of CNPq. We are grateful to the two anonymous reviewers for careful comments that improved this manuscript.

\section{ARTICLE INFORMATION}

Manuscript ID: 2020009. Received on: 02/08/2020. Approved on: 08/24/2020.

F.G.V.: conceptualization, formal analysis, funding acquisition, investigation, methodology, writing, review; V.R.S.: formal analysis, investigation, writing, review; M.L.A.: conceptualization, funding acquisition, resources, writing, review; L.V.W.: conceptualization, formal analysis, investigation, writing, review; S.A.M.: formal analysis, investigation, writing, review; M.G.R.: formal analysis, investigation, writing, review; F.T.F.: formal analysis, investigation, writing, review; M.G.S.: conceptualization, formal analysis, funding acquisition, investigation, methodology, writing, review.

Competing interests: The authors declare no competing interests.

\section{REFERENCES}

Aller R.C. 1982. Carbonate dissolution in nearshore terrigenous muds: the role of physical and biological reworking. The Journal of Geology, 90(1):79-95.

Arai M. 2014. Aptian/Albian (Early Cretaceous) paleogeography of the South Atlantic: a paleontological perspective. Brazilian Journal of Geology, 44(2):339-350. http://doi.org/10.5327/Z2317-4889201400020012

Armstrong H.A., Brasier M.D. 2005. Microfossil, stable isotopes and oceanatmosphere history. Microfossils. ${ }^{\text {nd }}$ ed. Malden: Blackwell Publishing, p. 25-34.

Assine M.L., Perinotto J.A. de J., Custódio M.A., Neumann V.H., Varejão F.G., Mescolotti, P.C. 2014. Sequências deposicionais do Andar Alagoas da Bacia do Araripe, Nordeste do Brasil. Boletim de Geociências da Petrobras, 22(1):3-28

Assine M.L., Quaglio F., Warren L.V., Simões M.G. 2016. Comments on paper by M. Arai "Aptian/Albian (Early Cretaceous) paleogeography of the South Atlantic: a paleontological perspective". Brazilian Journal of Geology, 46(1):3-7. https://doi.org/10.1590/2317-4889201620150046A

Barbosa J.A., Hessel M.H., Neumann V.H. 2004. Bivalves da Formação Crato, Bacia do Araripe. Paleontologia em Destaque, 20:41-42.

Barnes R.S.K. 1989. What, if anything, is a brackish-water fauna? Transactions of the Royal Society of Edinburgh: Earth Sciences, 80(3-4):235240. https://doi.org/10.1017/S0263593300028674

Beurlen K.G. 1963. Geologia e estratigrafia da Chapada do Araripe. In Congresso Brasileiro de Geologia. Anais... Recife: Sociedade Brasileira de Geologia, p. 47.

Brett C.E., Baird G.C. 1986. Comparative taphonomy: a key to paloenvironmental interpretation based on fossil preservation. Palaios, 1(3):207-227. https://doi.org/10.2307/3514686

Bright J., Cohen A.S., Starratt S.W. 2018. Distinguishing brakish lacustrine from brackish marine deposits in the stratigraphic record: A case study from the late Miocene and early Pliocene Bouse Formation, Arizona and California, USA. Earth-Science Reviews, 185:974-1003. https://doi. org/10.1016/j.earscirev.2018.08.011

Bruno A.P.S., Hessel M.H. 2006. Registros paleontológicos do Cretáceo marinho da Bacia do Araripe. Estudos Geológicos, 16(1):30-49.
Buatois L.A., Mángano M.G. 2011. Ichnology: Organism-substrate interactions in space and time. Cambridge: Cambridge University Press, $358 \mathrm{p}$.

Buatois L.A., Mángano M.G., Maples C., Lanier W.P. 1997. The paradox of nonmarine ichnocaunas in tidal rhythmites: Integrating sedimentologic and ichnologic data from the Late Carboniferous of Eastern Kansas, USA. Palaios, 12(5):467-481.

Catto B., Jahnert R.J., Warren L.V., Varejão F.G., Assine M.L. 2016. The microbial nature of laminated limestones: Lessons from the Upper Aptian, Araripe Basin, Brazil. Sedimentary Geology, 341:304-315. https://doi. org/10.1016/j.sedgeo.2016.05.007

Cohen A. 1989. The taphonomy of gastropod shell accumulations in large lakes: An example from Lake Tanganyika, Africa. Paleobiology, 15(1):26-45. https://doi.org/10.1017/S0094837300009167

Coimbra J.C., Arai M., Carreño A.L. 2002. Biostratigraphy of Lower Cretaceous microfossils from the Araripe basin, northeastern Brazil. Geobios, 35(6):687-698. https://doi.org/10.1016/ S0016-6995(02)00082-7

Custódio M.A., Quaglio F., Warren L.V., Simões M.G., Fürsich F.T., Perinotto J.A.J., Assine M.L. 2017. The transgressive-regressive cycle of the Romualdo Formation (Araripe Basin): Sedimentary archive of the Early Cretaceous marine ingression in the interior of Northeast Brazil. Sedimentary Geology, 359:1-15. https://doi.org/10.1016/j.sedgeo.2017.07.010

Fürsich F.T., Custódio M.A., Matos S.A., Hethke M., Quaglio F., Warren L.V., Assine M.L., Simões M.G. 2019. Analysis of a Cretaceous (late Aptian) high-stress ecosystem: The Romualdo Formation of the Araripe Basin, northeastern Brazil. Cretaceous Research, 95:268-296. https://doi. org/10.1016/j.cretres.2018.11.021

Fürsich F.T., Oschmann W. 1993. Shell beds as tools in basin analysis: the Jurassic Kachchh, western India. Journal of the Geological Society, 150(1):169-185. https://doi.org/10.1144/gsjgs.150.1.0169

Goldberg K., Preamor E., Bardola T., Souza P.A. 2019. Aptian marine ingression in the Araripe Basin: Implications for paleogeographic reconstruction and evaporite accumulation. Marine and Petroleum Geology, 107:214-221. https://doi.org/10.1016/j.marpetgeo.2019.05.011 
Gomez A.A., Jaramillo C.A., Parra M., Mora A. 2009. Huesser Horizon: A lake and a marine incursion in northwestern South America during the Early Miocene. Palaios, 24(4): 199-210. http://doi.org/10.2110/palo.2007.p07-074r

Gross M., Ramos M.I.F., Piller W.E. 2016. A minute ostracod (Crustacea: Cytheromatidae) from the Miocene Solimões Formation (western Amazonia, Brazil): evidence for marine incursions? Journal of Systematic Palaeontology, 14(7):581-602. https://doi.org/10.1080/14772019.2015.1078850

Haq B.U. 2014. Cretaceous eustasy revised. Global and Planetary Change, 113:44-58. https://doi.org/10.1016/j.gloplacha.2013.12.007

Heads S.W., Martill D.M., Loveridge R.F. 2008. Palaeoentomological Paradise: The Cretaceous Crato Formation of Brazil. Bulletin of the Royal Entomology Society, 32(2):91-98.

Heimhofer U., Ariztegui D., Lenniger M., Hesselbo S.P., MartillD.M., Rios-Netto A.M. 2010. Deciphering the depositional environment of the laminated Crato fossilbeds(Early Cretaceous,Araripe Basin,North-easternBrazil).Sedimentology, 57(2):677-694. https://doi.org/10.1111/j.1365-3091.2009.01114.x

Heimhofer U., Hochuli P.A. 2010. Early Cretaceous angiosperm pollen from a low-latitude succession (Araripe Basin, NE Brazil). Review of Paleobotany and Palynology, 161(3-4):105-126. https://doi.org/10.1016/j. revpalbo.2010.03.010

Hoefs J. 2004. Stable Isotope in Geochemistry. $5^{\text {th }}$ ed. Germany: SpringerVerlag, 244 p.

Kabat A.R., Hershler R. 1993. The prosobranch snail family Hydrobiidae (Gastropoda: Rissooidea): review of classification and supraspecific taxa. Smithsonian Contributions to Zoology, 547:1-94. https://doi.org/10.5479/ si.00810282.547

Keller G., Adatte T., Bajpai S., Mohabey D.M., Widdowson M., Khosla A., Sharma R., Khosla S.C., Gertsch B., Fleitmann D., Sahni A. 2009. K-T transition in Deccan Traps of central India marks major marine seaway across India. Earth and Planetary Science Letters, 282(1-4):10-23. https:// doi.org/10.1016/j.epsl.2009.02.016

Kidwell S.M., Fürsich F.T., Aigner T. 1986. Conceptual framework for the analysis of fossil concentrations Palaios, 1(3):228-238. http://doi. org/10.2307/3514687

MabesooneJ.M.,TinocoI.M.1973.PaleoecologyofAptianSantanaFormation (northeastern Brazil). Palaeogeography, Palaeoclimatology, Palaeoecology, 14(2):97-118. https://doi.org/10.1016/0031-0182(73)90006-0

Maisey J.H. 1991. Santana Fossils: An Illustrated Atlas. New Jersey: T.F.G. Publications, $459 \mathrm{p}$.

Martill D.M., Bechly G., Loveridge R.F. 2007a. The Crato Fossil Beds of Brazil: Window into an Ancient World. Cambridge: Cambridge University Press, $625 \mathrm{p}$.

Martill D.M., Loveridge R.F., Andrade J.A.F.G., Cardoso A.H. 2005. An unusual occurrence of amber in laminated limestones: the Crato Formation Lagerstätte (Early Cretaceous) of Brazil. Palaeontology, 48(6):1399-1408. https://doi.org/10.1111/j.1475-4983.2005.00517.x

Martill D.M., Loveridge R., Heimhofer U. 2007b. Halite pseudomorphs in the Crato Formation (Early Cretaceous, Late Aptian-Early Albian), Araripe Basin, northeast Brazil: further evidence for hypersalinity. Cretaceous Research, 28(4):613-620. https://doi.org/10.1016/j.cretres.2006.10.003

Martill D.M., Wilby P. 1993. Stratigraphy. In: Martill D.M. (Ed.). Fossils of the Santana and Crato Formations, Brazil. Dorchester: Palaeontological Association, p. 20-50.

Mas R., Arribas M.E., González-Acebrón L., Quijada I.E., Campos-Soto S., Suarez-Gonzalez P., Sacristán-Horcajada S., Arribas J., Benito M.I., PérezGarrido C., Alonso A. 2018. Coastal wetlands as markers of transgression in proximal extensional systems (Berriasian, W Cameros Basin, Spain). Journal of Iberian Geology, 45:1-27. https://doi.org/10.1007/s41513-018-0086-y

Matos R.M.D. 1992. The Northeast Brazilian Rift System. Tectonics, 11(4):766-791. https://doi.org/10.1029/91TC03092

Miall A.D. 2016. Facies analysis. In: Mial A.D. (Ed.). Stratigraphy: A modern synthesis. Switzerland: Springer International Publishing, p. 77-159.

Miranda T.S., Santos R.F., Barbosa J.A., Gomes I.F., Alencar M.L., Correia O.J., Falcão T.C., Gales J.F.W., Neumann V.H. 2018. Quantifying aperture, spacing and fracture intensity in a carbonate reservoir analogue: Crato Formation, NE Brazil. Marine and Petroleum Geology, 97:556-567. https:// doi.org/10.1016/j.marpetgeo.2018.07.019
Neumann V.H., Assine M.L. 2015. Stratigraphic Proposal to the Post-Rift I Tectonic-Sedimentary Sequence of Araripe Basin, Northeastern Brazil. In: International Congress on Stratigraphy, 2, 2015. Berichte des Institutes für Erdwissenschaften der Universität Graz, p. 274.

Neumann V.H., Borrego A.G., Cabrera L., Dino R. 2003. Organic matter composition and distribution through the Aptian-Albian lacustrine sequences of the Araripe Basin, northeastern Brazil. International Journal of Coal Geology, 54(1-2):21-40. https://doi.org/10.1016/ S0166-5162(03)00018-1

Petri S., Coimbra A.M., Amaral G., Ponçano W.L. 1986. Guia de nomenclatura estratigráfica. Revista Brasileira de Geociências, 16(4):376-415.

Ponder W.F. 1984. A review of the Genera of the Rissoidae (Mollusca: Mesogastropoda: Rissoacea). Records of the Australian Museum, (4):1-221. https://doi.org/10.3853/j.0812-7387.4.1985.100

Quijada I.E., Suarez-Gonzalez P., Benito M.I., Mas R. 2016. Tidal versus continental sandy-muddy flat depotits: Evidence from the Oncala Group (Early Cretaceous, N Spain). In: Tessier B., Reynaud, J.-Y. (Eds.). Contributions to Modern and Ancient Tidal Sedimentology. Proceedings of the Tidalites 2012 Conference... IAS, p. 133-159.

Rodrigues M.G., Matos S.A., Varejão F.G., Fürsich F.T., Warren L.V., Assine M.L., Simões M.G. 2020. Short-lived "Bakevelliid-sea" in the Aptian Romualdo Formation, Araripe Basin, Northeastern Brazil. Cretaceous Research, 115:104555. https://doi.org/10.1016/j.cretres.2020.104555

Santos F.H., Azevedo J.M., Nascimento Junior D.R., Souza A.C.B, Mendes M., Bezerra I., Limaverde S. 2017. Análise de fácies e petrografia de uma seção do Membro Crato em Nova Olinda (CE): contribuições à história deposicional e diagenética do neoaptiano na Bacia do Araripe. Geologia USP. Série Científica, 17(1):3-18. https://doi.org/10.11606/issn.2316-9095.v17-319

Silva V.R., Varejão F.G., Matos S.A., Fürsich F.T., Skawina A., Schneider S., Warren L., Assine M.L., Simões M.G. 2020a. Cratonaia novaolindensis gen. et sp. nov. (Unionida, Silesunionoidea) from the Aptian of Brazil (Araripe Basin), and its implications on the early evolution of freshwater mussels. Cretaceous Research, 107:104275. https://doi.org/10.1016/j. cretres.2019.104275

Silva V.R., Varejão F.G., Matos S.A., Rodrigues M.G., Fürsich F.T., Skawina A., Schneider S., Warren L.V., Assine M.L., Simões M.G. 2020b. New freshwater mussels (Bivalvia, Unionida) with potentical trigonioidid and hyriid affinities from the Early Cretaceous of Brazil. Geobios, 61:41-54. https://doi.org/10.1016/j.geobios.2020.06.001

Taylor A.M., Goldring R., 1993. Description and analysis of bioturbation and ichnofabric. Journal of the Geological Society, 150(1):141-148. https:// doi.org/10.1144/gsigs.150.1.0141

Törő B., Pratt B.R. 2016. Sedimentary record of seismic events in the Eocene Green River Formation and its implications for regional tectonics on lake evolution (Bridger Basin, Wyoming). Sedimentary Geology, 344:175-204. https://doi.org/10.1016/j.sedgeo.2016.02.003

Van Damme D., Bogan A.E., Dierick M. 2015. A revision of the Mesozoic naiads (Unionoida) of Africa and the biogeographicimplications. Earth-Science Reviews, 147:141-200. https://doi.org/10.1016/j.earscirev.2015.04.011

Varejão F.G. 2019. Abordagem multi-indicadores do sistema misto carbonáticosiliciclástico da Formação Crato: evolução sedimentar, paleogeografia e tectônica. $\mathrm{PhD}$ thesis, Universidade Estadual Paulista "Júlio de Mesquita Filho", 163 p.

Varejão F.G., Warren L.V., Simões M.G., Fürsich F.T., Matos S.A., Assine M.L. 2019a. Exceptional preservation of soft tissues by microbial entombment: insights into the taphonomy of the Crato Konservat-Lagerstätte. Palaios, 34(7):331-348. https://doi.org/10.2110/palo.2019.041

Varejão F.G., Fürsich F.T., Warren L.V., Matos S.A., Rodrigues M.G., Assine M.L., Sales A.M.F., Simões M.G. 2019b. Microbialite fields developed in a protected rocky coastline: The shallow carbonate ramp of the Aptian Romualdo Formation (Araripe Basin, NE Brazil). Sedimentary Geology, 389:103-120. https://doi.org/10.1016/j.sedgeo.2019.06.003

Warren L.V., Varejão F.G., Quaglio F., Simões M.G., Fürsich F.T., Poiré D.G., Catto B., Assine M.L. 2017. Stromatolites from the Aptian Crato Formation, a hypersaline lake system in the Araripe Basin, northeastern Brazil. Facies, 63(3):1-19. https://doi.org/10.1007/s10347-016-0484-6

Wesselingh F.P., Räsänen M.E., Irion G., Vonhof H.B., Kaandorp R., Renema W., Romero Pittman R., Gingras M. 2002. Lake Pebas: a palaeoecological reconstruction of a Miocene long-lived lake complex in western Amazonia. Cenozoic Research, 1(1-2):35-81. 